\title{
Természetvédők és kutatók ismeretei az eurázsiai hód kapcsán a Kárpát-medencében I.: elterjedés, életnyomok, az együttélés lehetőségei, az elhullás okai
}

\author{
Juhász Erika ${ }^{1}$, Biró Marianna ${ }^{2}$, Ulicsni Viktor ${ }^{2}$ és Molnár Zsolt ${ }^{2}$
}

${ }^{1}$ Eötvös Loránd Tudományegyetem, Növényrendszertani, Ökológiai és Elméleti Biológiai Tanszék, 1117 Budapest, Pázmány Péter stny. 1/C.

${ }^{2}$ MTA Ökológiai Kutatóközpont, Ökológiai és Botanikai Intézet, 2163 Vácrátót, Alkotmány u. 2-4.

E-mail: erikamaria.juhasz@gmail.com

\begin{abstract}
Összefoglaló: Az eurázsiai hóddal kapcsolatos szakmai ismeretek jelentős része a helyi természetvédők és kutatók publikálatlan tudásanyagában található. Kárpát-medencében élő szakembereket kértünk fel arra, hogy osszák meg velünk tapasztalataikat a faj elterjedését, életmódját és a konfliktust érintő kérdésekben. Az elhangzott információkat szakirodalmi környezetben értelmezve új öszszefüggéseket és kutatási irányokat kerestünk. A hód valamennyi folyónkon jelen van, az állomány növekszik, ezzel párhuzamosan az együttélés lehetőségének megteremtése egyre több térségben jelent kihívást. A hód általi fadöntés mellett a faj gátépítése, valamint üregásási tevékenysége is konfliktusok forrása. Adatközlőink válaszai fontos hézagokat töltenek be, általuk válik lehetővé a hazai tudásanyag újraértelmezése, szintetizálása és a megismert jelenségek nyugat-európai példákkal való összevetése.
\end{abstract}

Kulcsszavak: Castor fiber, strukturált interjú, elterjedés, együttélés, gyérítés

\section{Bevezetés}

Az eurázsiai hód (Castor fiber L., 1758) az 1980-as évek végén kezdődött spontán kolonizáció és az 1996-2008 közötti WWF visszatelepítések következtében jutott el Magyarországra (Bajomi 2011). Tehát mindössze két-három évtizede van újra jelen a hazai emlősfaunában. Ezalatt az idő alatt számos értékes, a fajjal kapcsolatos alapvető információk rendszerezését szolgáló publikáció született (Bozsér 2001, Haarberg 2007, Bajomi 2011, Czabán 2016), melyek a hód aktuális helyzetét, a visszatelepítéseket, a szerzők saját tapasztalatait és a nemzetközi szakirodalomban fellelhetö ismereteket mutatják be. Magyarország több térségében vizsgálták a hódok elterjedését, állománynagyságát: a Fertő-Hanság Nemzeti Park területén (Bozsér 2003, Varju 2008, Czabán 2017), az Alsó-Duna völgyben 
(Baja Ifjúsági Természetvédelmi Egyesület 2011), a Mura mentén (Lelkes 2013), a Közép-Tiszán (Tallósi 2013), újabban pedig Borsod-Abaúj-Zemplén megyében (Arlett 2016) és a Dél-Alföldön (Juhász 2018). A fent felsorolt jelentések és egyéb kutatási anyagok említést tesznek a hód táplálékválasztásáról, de ezt a kérdéskört célzottan eddig kevesen és csak lokálisan elemezték (Czabán 2003a, Právics 2012, Varju \& Jánoska 2015, Juhász 2017).

Az Európa különböző országaiban élő hódok táplálkozásáról, ökológiai hatásairól szóló tudományos munkák (Nolet et al. 1994, Hägglund \& Sjöberg 1999, Ganzhorn \& Harthun 2000, Haarberg \& Rossel 2006, Dvořák 2013) eredményei a magyarországi hódélőhelyek esetében csak korlátozottan értelmezhetőek. A Kárpát-medence mint természeti és tájtörténeti szempontból önálló földrajzi egység a hód számára egyedi élőhelyeket, életfeltételeket és interakciókat biztosíthat.

Magyarországon a hódokkal kapcsolatos szakmai tudás jelentős részét a helyi természetvédők és kutatók publikálatlan, saját tapasztalatokon alapuló ismeretei adják. Az itt bemutatott vizsgálatunk célja ezek átfogó feltárása az ország valamennyi régiójának megfelelő reprezentálásával, továbbá a regionális különbségek értelmezése valamennyi vizsgált témakörben.

A gyakorlati természetvédelemben dolgozó szakemberek tudásanyaga értékes információkkal egészítheti ki a szakirodalmat (Fazey et al. 2006.). Ezen tudásanyag megismerése fontos szereppel bírhat a természetvédelmet érintő döntések meghozatalában, a részvételi tervezésben (Bojórquez-Tapia et al. 2003), valamint a természetvédők és más érdekcsoportok közös céljainak és konfliktushelyzeteinek feltérképezésében (Molnár et al. 2016). A különbözö érdekcsoportok bevonásával megvalósuló részvételi tervezést széles körben alkalmazzák, módszertana és eredményei tudományos kutatások tárgyát képezik (Kovács et al. 2015, 2016). A gyakorlati természetvédők megkérdezése segítheti az aktuális és jövőbeli természetvédelmi kihívások meghatározását (Mihók et al. 2014), továbbá a tájtörténet és a helyi természeti értékek feltárását (Varga 2017). Szakmai tudásuk összegyüjtése, felhasználása a hóddal kapcsolatos átfogó kutatások megalapozásához is hozzájárulhat.

Ebben a publikációban (összegzésünk első részében) az elemzett kérdéseket, témaköröket négy blokkba csoportosítottuk, melyek a hód elterjedése, a jelenlétére utaló életnyomok, az együttélés lehetőségei és az elhullás okai. A második részben a hód életmódjával (táplálkozásával, építő-tevékenységével, élőhelyválasztásával) kapcsolatos megfigyeléseket fogjuk bemutatni. Bízunk abban, hogy eredményeinkkel hasznos áttekintést adhatunk a gyakorlati természetvédelem számára is. 


\section{Módszerek}

Magyarország területét a hivatalos természetvédelem intézményrendszere nemzeti park igazgatósági müködési területekre osztja. A tíz nemzeti park igazgatóság név szerint: Aggteleki (ANPI), Balaton-felvidéki (BFNPI), Bükki (BNPI), Duna-Dráva (DDNPI), Duna-Ipoly (DINPI), Fertő-Hanság (FHNPI), Hortobágyi (HNPI), Kiskunsági (KNPI), Körös-Maros (KMNPI) és Örségi Nemzeti Park Igazgatóság (ÖNPI) (http1). A hazai természetvédelem szerkezetét követve a hódokkal kapcsolatos szakmai tudás feltárását e tíz térség köré szerveztük. Mivel az összes térséget megfelelően kívántuk reprezentálni, ezért valamennyi nemzeti park igazgatóság esetében egy-egy természetvédelmi szakmai vezetőt (zoológiai referens, osztályvezető, igazgatóhelyettes, igazgató) kértünk meg arra, hogy ajánljon 4-4 személyt, aki gyakorlati természetvédő vagy kutató, a nemzeti park igazgatóság müködési területén él vagy dolgozik (nem feltétlenül a nemzeti park igazgatóság munkatársa), és feltételezhetö, hogy azok között a szakemberek között van, akik a térségben a legtöbbet tudják a hódról. További 9 magyarországi adatközlőt (5 kutatót, 2 nemzeti park igazgatósági alkalmazottat, valamint 2 szakirányú végzettséggel rendelkezö, ökoturizmussal és természetvédelmi célú ismeretterjesztéssel foglalkozó személyt) előzetes ismereteink vagy más személyek többszöri javaslata alapján választottunk ki. A szélesebb, kárpát-medencei kitekintés érdekében 6 romániai magyar szakembert is felkértünk kérdéseink megválaszolására. Kutatásunk során összesen 55 szakemberrel (49 magyarországi, 6 romániai) készítettünk strukturált interjút. A Köszönetnyilvánításban név szerint felsoroltuk őket. Az interjúkat az adatközlők hozzájárulásával diktafonra rögzítettük, majd az elhangzott információkat táblázatos formába rendeztük és elemeztük.

Adatközlőink mindegyike felsőfokú végzettséggel rendelkezett, átlagéletkoruk 42 év volt. A legfiatalabb interjúalany 28, a legidősebb 63 éves volt. A romániaiak megkérdezésére már 2014-ben sor került, egy magyarországi adatközlővel ugyancsak ekkor interjúztunk. Az összes többi interjú 2017 végén, 2018 elején készült. Az anonimitás megőrzése érdekében az interjúkból való idézés során az adatközlőket véletlenszerü kódnevekkel láttuk el $(\mathrm{H}=$ magyarországi adatközlő, $\mathrm{R}$ = romániai adatközlő, kódnevek: H1-H49, R1-R6).

Az első részben a faj elterjedését, a kolonizációt, az életnyomokat, az ismert konfliktustípusokat, a konfliktusmegelőzési és konfliktusmérséklési lehetőségeket, az együttélés lehetőségeit, a gyérités témakörét, valamint a természetes ellenségeket és az elhullás okait mutatjuk be. Az elemzés alapját képező interjúkérdéseket az 1 . függelék tartalmazza. A hód életmódjával a második részben foglalkozunk majd. 
Az eredmények valamennyi állítása mögött zárójelben tüntettük fel az adatközlők általi említések számát. Ez alól egyedül az elterjedés témakörét érintő információk képeznek kivételt, mivel azok minden esetben egyediek. Az elterjedéssel kapcsolatos megfigyelések csupán a kolonizáció folyamatának apró lépései, önálló felsorolásban nehezen, szakirodalmi környezetben viszont jól értelmezhetőek, esetenként kapcsolatot teremtenek korábbi, publikált adatok között, amelyeket a diszkusszióban részletezünk. Az interjúfonál szabad felsoroláson alapuló (freelisting) kérdéseket is tartalmazott. Az ilyen kérdésekre adott válaszok egy része mögött alacsony említésszám szerepel. Az, hogy valamelyik válaszlehetőséget kevés adatközlő fogalmazza meg önállóan egy adott kérdés kapcsán, nem feltétlenül függ össze a megállapítás jelentőségével, tudományos értékével.

\section{Eredmények}

\section{Elterjedés}

Az adatközlők szerint az eurázsiai hód hazánk valamennyi folyóján jelen van. Főként a Duna, a Dráva és a Tisza mentén terjedve jutott el a mellékfolyókra, majd a még kisebb víztestekre. Az interjúk során elhangzott információk alapján a hódok magyarországi elterjedésének folyamatáról a következő főbb megállapításokat tehetjük: A Szigetköz spontán kolonizációja 1985-86 környékén kezdődött. Az első évek szórványos észlelései után az 1990-es években fokozatos állománynövekedés indult meg. A megkérdezettek 1991-92-ben találkoztak elöször hódrágásokkal a Mosoni-Dunán. Ezt követően ,,egyre több helyen jelent meg mind a Mosoni-Dunán, mind a Nagy-Dunának a mellékágrendszerében, valamint a Nagy-Dunán is, és aztán onnan pedig a két Duna közötti csatornahálózaton" (H40). A 2000 és 2002 között történt hansági telepítések következtében létrejött hódállomány a csatornák mentén terjedve még abban az évtizedben kapcsolatba kerülhetett a szigetközivel.

Az adatközlőink szerint a hód a 2000-es években indult meg Komárom irányába és jelent meg az Erebe-szigeteken. Esztergom környékéről, a Búbánatvölgyböl pedig már az 1990-es évek végéről is származnak adatok. A 2000-es évek közepétől a Közép-Dunán is gyakoribbá vált a faj. Az Ipolyon 2004-ben észlelték (az első helyszín Ipolypásztó), innen jutott el néhány börzsönyi patakra. A Közép-Dunán a jelenlegi állomány másik forrása az 1996-1998-as és 2004-es gemenci telepítés, ebből az irányból érhette el a hód többek között a Siót és a Kapost. A DDNPI területén feltételezik, hogy már a 2000-es évek közepén érkezhetett néhány példány a Duna felsőbb szakaszáról is. 
A Dráva magyarországi szakaszán 2007-ben történt telepítés, de az adatközlők már ennél korábbi, vízvári előfordulásról is beszámoltak, utalva az 1990-es évek végén, a horvátországi Dráva-szakaszon elengedett példányokra. A horvátországi telepítés következtében 1998-ban a Murán, 1999-ben a Kerkán, néhány évvel később pedig a Mura menti holtágakon is megtelepedett a faj, és nagyon erős állománya alakult ki a Mura-menti Tájvédelmi Körzetben.

Az ÖNPI területére főként az FHNPI irányából érkezhettek egyedek, amit az ottani adatközlők a 2000-es évek elején kezdtek érzékelni, de hatásuk az utóbbi években vált jelentössé. „Olyan 3-4 éve nem volt ez akkora nagy slágertéma talán, tehát mintha egy ilyen exponenciális növekedése lenne az állománynak" (H16), ,,2014-ben még kuriózum volt, [...] 2016-ban kezdett nagyon nöni” (H15).

A Hármas-Körösön a megkérdezett természetvédelmi szakemberek először 2010-ben észlelték a hódot. A Maroson feltételezik, hogy legalább tíz éve jelen vannak, ennél pontosabb információ nem áll rendelkezésre. 2010-ben találták az első várat a Bodrogon, ettől az évtől kezdve egyre gyakoribbá váltak a megfigyelések az ANPI különböző területein. 2014-re már a Sajót, a Hernádot, valamint a Taktaköz és a Bodrogzug kisebb vízfolyásait is kolonizálta a faj.

A hód előfordul csatornákon, akár fél méter mély belvízelvezetőkön is, továbbá keskeny patakokon (pl. Concó-patak, Cserge-patak, bakonyi patakok). 2016/17 telén a Kis-Balatonnál és a Balaton mellett, Palóznaknál is találkoztak az életnyomaival. A faj gyors terjedését és alkalmazkodóképességét mutatja, hogy régóta él hód belvárosi területeken (pl. Mosonmagyaróváron, Szombathelyen, Kapuváron, Szegeden, illetve Budapesten legalább öt helyszínen). A Dunántúlon és ÉszakMagyarországon van még néhány olyan terület (elsősorban kis, állandó vizü patak vagy csatorna, más víztestekkel összeköttetésben nem álló tó), ahol a hód a gyüjtött információk szerint egyelőre nem fordul elő, de számítanak a megjelenésére (ANPI, BFNPI, BNPI, DINPI, HNPI, ÖNPI). Az FHNPI és a DDNPI esetében ilyenekröl nem számoltak be. „Némi terjeszkedési lehetőség van még a lakott területeken, de szerintem így is a kisalföldi állomány már régen kibocsátó." (H42). Bizonyos helyeken a faj megjelenése az adatközlők szerint nem várható (hegyi patakok az Északi-középhegységben, a Mecsekben, a Köszegi-hegységben, valamint időszakos vízfolyásokon). Délkelet-Magyarországon (KMNPI, KNPI) az Alsó-Tisza, a Maros és a Körös hullámterében is jelentős állományt valószínüsítenek, ám a faj mentett oldali ártereken való terjedése még nem jellemző (csak néhány kisebb csatornán találhatók rágásnyomok).

Az FHNPI területére rálátással rendelkező adatközlők közül ketten vélték úgy, hogy már nem nő a hódok száma a térségben, mások szerint valamilyen mértékben még növekszik. A többi térségben egyetlen szakember gondolta úgy, hogy az egyedszám stagnál, amit azzal magyarázott, hogy az egyedek ,uújabb helyeken 
jelennek meg, de a régebbiekről eltünnek” (H13). Rajta kívül mindenki mérsékelt vagy erős növekedést érzékelt. Ahol a növekedés üteme lassul, ott a következő főbb gondolatok fogalmazódtak meg: „Nem túl sok új hódcsaládot fog tudni elviselni a terület." (H48), ,Időnként, ritkán komoly revirharcok nyomait is látjuk, tehát ilyen nagy véres tappancsnyomok az iszapban, kitépett ször.” (H49), „A Duna menti rész az talán kezd beállni, [...] onnan van egy kis kirajzás, [...] most fognak kezdődni azok a bajok...” (H4). Állománycsökkenést senki sem tapasztalt.

A kanadai hód (Castor canadensis Kuhl, 1820) korábbi előfordulásával kapcsolatban a következő információkról számoltak be: Az 1990-es évek elején tévedésből néhány kanadai hódot telepítettek a HNPI területére. Ezek egyike Poroszló környékén egy varsába fulladt bele, néhány másik pedig az Eger-csatornára is feljutott, később eltủnt. Hordódon 2001-ben befogtak egy fiatal egyedet, több példány nem került elő. Egy adatközlőnk elmondása alapján 1990-ben az osztrák határon, a Pinka-patak medrében egy lelőtt kanadai hód tetemét találták meg. Ez az egyed Ausztria irányából érkezhetett. A példány preparátuma a Savaria Múzeum gyüjteményének része. Egy alsószölnöki, WWF Magyarország általi visszatelepítések előtti adatról is említést tettek, de ezt más forrás tudomásunk szerint nem igazolja.

Az interjúalanyok közül 42-en mondták azt, hogy az eurázsiai hód a 19. században, esetleg a 20. század elején pusztult ki az országból, közülük 9-en említették a szakirodalomban fellelhető (Brehm 1989) 1854-es vagy 1865-ös évszámot. Utóbbi a történelmi Magyarország területére vonatkozik. Egy adatközlő egy kevésbé ismert szakirodalmi forrásra (Fintha 2012) hívta fel a figyelmünket, mely szerint 1907-ben hódot löttek Gulácson, valamint 1985 és 1990 között több alkalommal figyelték meg a fajt Szabolcs-Szatmár-Bereg megyében.

\section{Életnyomok}

Az interjúk során elhangzott információk bővelkednek személyes tapasztalatokban. Az interjúalanyok legtöbbje terepi munkája során már találkozott hóddal (46). A hódot leginkább éjjel lehet megfigyelni (55), de egyes területeken nappal is mozoghat (20). Ebben a tekintetben jelentős évszakos különbség nem került szóba, a rágásokat azonban leginkább a „téli időszakban”, októbertől áprilisig figyelhetjük meg (33 említés és 4 ezzel ellentétes információ), 7 adatközlő szerint ennek oka nem vagy nem kizárólag a téli intenzívebb rágási tevékenységben, hanem a lomb általi takarás hiányában keresendö. A faj jelenlétére elsősorban a rágás, fadöntés alapján következtetnek (55), mely legnagyobb mértékben a puhafafajokat (Salix spp., Populus spp.) érinti (52). Egyes területeken a hód kijárhat a szántóföldekre, elsősorban kukoricaföldekre (43), amiről a vízbe húzott kukoricaszárak is árulkodhatnak (5). Az egyéb lágyszárúakkal való táplálkozás (46) 
többnyire nem feltűnő, az adatközlőknek kevés az ezzel kapcsolatos tapasztalata, föként a szakirodalmi ismeretükre hivatkoztak a kérdés megválaszolásakor. A téli időszakban vékony gallyakból és lágyszárú növényekből a hód élelemraktárt készíthet a kotorék bejárata előtt (8). A táplálkozás nyomain kívül hódkotorékot, várat vagy beszakadt üreget (összesen 43) és gátépítést (20) is gyakran észlelnek, de a hód építési hajlamával kapcsolatban megoszlanak a vélemények. Hódgátak Magyarországon keskeny csatornákon, patakokon jellemzőek (19), ezért csak ott találkozhatunk velük, ahol ilyen víztesteken is elöfordul a faj. Más térségekben az építkezést az adatközlők egy része (tévesen) kizárólag a kanadai hód szokásának tartja (10).

Ismert életnyomok még a csapa és a csúszda (28), a két víztest összekötésének érdekében képzett, részben kijárt, részben ásott csatorna (4), a hódpézsmával (castoreummal) történő, jellegzetes szagú területjelzés (7), az összehordott és körberágott ágakból álló táplálkozó hely (4), a vízen úszó megrágott ágak (3), a kotorék fölötti „,szellőzőpontok” (3), a jégen képzett lék (3), a patakmeder peremének iszappal való tapasztása (1), valamint az elhullatott szőr (1). A hód ürüléke ,,nagyon jellegzetes, golflabda nagyságú tömör fürészporgolyó" (H11), ezt 6 adatközlő említette. A hódok jelenlétéről egyes esetekben csak az egyed megfigyelésének (15), riasztásként szolgáló farokcsapásuk észlelésének (5), tetemek megtalálásának (6) útján vagy lakossági bejelentés következtében (3) szereztek tudomást.

\section{„Ahol ember és hód együtt használná a tájat”}

Az eurázsiai hód az adatközlők szerint jellemzően legfeljebb 5 méterre (5), 5-10 méterre (6), 10-20 méterre (24) vagy 20-30 méterre (8) távolodik el a víztől, s csupán 4-en állították azt, hogy a víz 30 méternél messzebbre történő elhagyása is általános az adott térségben. 50 méternél távolabbi alkalomszerü észlelést az alapvetően szük mozgáskörzetet feltételezők közül 17-en említettek. Ez utóbbi megfigyelések gyakran kukoricaföldön történtek (5). Mások is vélekedtek úgy, hogy a mozgáskörzet nagyságában szerepe lehet a növényzet takarásának: , 40-50 méter, ha fedett, kökénybokros a megközelitöút. [...] Az átlagos olyan 10-20 méter lehet" (H49). Erdőgazdálkodókat negatívan érintő hódhatás akkor fordul elö, amikor az emberi tevékenység ezen a keskeny vízparti zónán belül is jelentős (9). A széles galériaerdők, a véderdő szerepét betöltő területek, továbbá a természetvédelmi területek szinte teljes mértékben mentesülnek az ilyen típusú konfliktusok alól (32). Jó példa erre a Tisza, a Körösök vagy a Mura hullámterének legtöbb szakasza. A vízparton álló nemesnyár kirágása által okozott erdészeti konfliktus (38) elsősorban a magángazdálkodókat érinti (10). A gyümölcsfák és más egyedi értéket képviselő fák kirágása (15) főként a vízparttal érintkező ingatlanok esetében járhat konfliktussal, de a Jeli Arborétumban (2) és a Vácrátóti Botanikus 
Kertben (3) is történt káresemény. A termények, elsősorban a kukorica fogyasztását minden térségben legalább egy adatközlő tapasztalta, azonban ez a hatás csak a Kerka mentén érzékelhető kisebb kárként. Jelentősége még itt is csekély, ,, $a$ vaddisznókár egy tizede" (H37).

Vízügyi részről felmerül a vízbe dőlt fák mederből történő eltávolításának igénye (24), főként mivel az így feltorlódó uszadék visszaduzzaszthatja a kisebb vízfolyásokat, valamint ,,megakad az ág a mütárgyakban, tehát általában a vizügyi létesitmények szempontjából jelent problémát” (H42). A hód általi gátépítésből adódó konfliktust a magyarországi adatközlők közül 21-en említették. Ugyanakkor a romániai adatközlők mindegyike ezt emelte ki a térségükben jellemző fő konfliktusforrásként. Leginkább Romániában jellemzö, hogy a parttal közvetlenül érintkező mezőgazdasági területek, kaszálók is elmocsarasodhatnak a gátépítés következtében.

Északnyugat-Magyarországon beszámoltak olyan esetekről is, amikor a csatornák mellett haladó gépjármü alatt egy-egy kotorék miatt beszakadt az út (11). Nagyon ritkán, elsősorban szük hullámterü folyók esetében (Marcal, Zagyva) jelentkező, de bizonyos esetekben az előzőeknél potenciálisan sokkal súlyosabb probléma az árvízvédelmi töltésbe történő kotorékásás, ami éppen áradásokkor történhet meg, amikor a hódnak magasabb térszínre kell költöznie: „,Megemelkedik a vizszint, kiönti a hódot az eredeti üregéböl. A hód nem problémázik rajta, és ás egy másikat. Legközelebb az árviźvédelmi töltés van." (H11). Annak ellenére, hogy mindössze néhány helyszínt érintett az országban (egyiken sem történt gátszakadás emiatt), 24-en hallottak erről a típusú hódkárról.

Megjegyezzük, hogy a hód rágási és építési tevékenysége, tájátalakítása ökológiai és természetvédelmi jelentőséggel is bír. 54 adatközlő említett valamilyen ökológiai hatást, természetvédelmi szempontból kedvező vagy kedvezőtlen következményt. A hatások jellege és nagysága élőhelytípusonként és térségenként is különbözhet.

A konfliktusok szempontjából szintén feltünő eltérés mutatkozik az ország különböző térségei között. Míg egyes területeken nagyszámú konfliktuspont együttesen jelentkezik, addig máshol - sok esetben a hódok magas egyedszáma ellenére is - a faj előfordulása szinte észrevétlen marad: „A Bodrogon, szerintem, meg a Tisza legtöbb szakaszán, a folyónál úgy elvész ez a jelenlét, [...] ha valaki nem nagyon figyeli öket" (H32).

A különböző hódkártípusok elleni védekezés lehetőségeivel kapcsolatban az adatközlők többsége nem rendelkezett saját tapasztalattal, ezért az elhangzott válaszok pusztán felvetések, nem konkrét javaslatok. Az ember számára különösen fontos, elsősorban rekreációs ökoszisztéma-szolgáltatást nyújtó fák (gyümölcsfák, parkfák, horgásztavak partján álló árnyékadó fák) egyedi védelmének (17) 
eszközei között a következőket sorolták fel: háló ( 2 említés konkrétum nélkül), drótháló (5), mủanyagháló ( 2 említés, de lásd diszkusszió), tápos zsákkal betakarás (1), egyedi fa körülkerítése (1 említés, Nyugat-Európában látta), lefestés (1) vagy kémiai, esetleg biológiai anyaggal lekenés $(8$ említés, 1 adatközlö szerint viszont nem válik be). Gazdálkodói érintettség esetén leggyakrabban a terület bekerítését említették (19), de a módszer anyagi (egyes esetekben természetvédelmi) vonzatait problémának tartották. Csatornák mentén, fóként a terménykár elleni védekezésben a villanypásztor alkalmazható (9). Egy adott területről való távoltartás további lehetőségeiként az alábbi ötletek merültek fel: kutyatartás (3), folyamatos emberi jelenlét (2), de ezek sokszor nem kivitelezhetőek. A vadriasztó (5), valamint általánosságban a riasztás (egyéb hanghatással: 2 említés, konkrétum nélkül: 2 említés) hatékonyságáról nincs ismeretük. Megjegyezzük, hogy a védett állatfajok egyedeinek riasztásához a természetvédelmi hatóság engedélye szükséges (1996. évi LIII. törvény a természet védelméről 74. §-a). Gazdálkodói tevékenységtől mentes hullámterek esetében ehhez hasonló vélemények is megfogalmazódtak: „,Nem tudom, mivel nincs ilyen jellegü kárunk, nem kellett ezzel foglalkoznunk" (H19).

Öt térségben a hódgátakat vízügyi okok miatt rendszeresen elbontják (11), de a hód azokat rövid időn, akár néhány napon belül visszaépíti (2). A gátépítéssel való lefolyás-akadályozás elleni védekezésre az áteresz beépítése nyújthat tartós megoldást (2). A hódgátak elbontása szintén engedélyköteles tevékenység.

Néhány ritkábban előkerülö, ökológiai ismereteken és terepi tapasztalatokon alapuló javaslat is elhangzott: Egy adatközlő hangsúlyozta, hogy a hód által kidöntött fa ágrendszerének (vágástéri hulladék) partszegélyen való otthagyása is mérsékelheti a gazdasági célú faültetvényekben jelentkező kárt. Ha a kidöntött fát teljes egészében eltávolítják, akkor a hód újabb törzsek rágására kényszerül a táplálékszerzés érdekében. ,Hagyni kell nekik, hogy ha egy fát kidöntenek, azt ők dolgozzák fel" (H48). Füzbokros állomány telepítése (de legalább a meglévők megőrzése) is csökkentheti az emberi szempontból értékes fák rágással való érintettségét (2). „A nagyobb törzseket is rágja, ugye. Gondolom, hogy elérje a vékony ágakat. [...] Ha erre jobban figyelnének, hogy meghagyják ezeket az ilyen bokorfizes szakaszokat, akkor kevesebbet döntögetne" (H32). Esetleg el lehet gondolkozni olyan fafaj vagy mezőgazdasági kultúra telepítésén, amit a hód kevésbé vagy egyáltalán nem fogyaszt (2). 7 adatközlő szerint a hódkár ellen nem lehet érdemben védekezni, vagy a legalább 10 méteres vízparti sáv gazdálkodásból való kivonása, megkímélése jelenthet megoldást (3). , Meg kell hagyni az élöhelyét" (H34).

Komolyabb konfliktus esetén, amikor az együttélés nem müködik, 5 adatközlö szerint az áttelepítés, 8 adatközlő szerint pedig egyes példányok elpusztítása lehet 
a végső alternatíva. Ebben a kérdésben nem volt egyetértés a megkérdezettek között. Vegyes vélemények hangzottak el a két módszerrel kapcsolatban: ,,Végső soron a csapdázás, illetve a kilövés az szóba jöhet” (H45). „Azok a legrosszabbak, tehát a csapdás befogás vagy eltüntetés a területröl.” (H47). „Kicsapdázni ezeket, és elvinni máshova. Csak általában nem nagyon van már hova telepiteni..." (H27). A letális megoldást is elfogadók egyetértenek abban, hogy a beavatkozás „,tudományos alapon, állománybecslésen kell nyugodjon” (H5). A következő vélemény is megfogalmazódott: „, A szabályozást nem engedném ki a természetvédelem kezéböl" (H7).

Az érintett térségben tapasztalatokkal nem rendelkező magyarországi adatközlők (37) közül mindössze 7 hallott arról, hogy 2016-tól kezdve Északnyugat-Magyarországon, szigorú keretek között már adtak ki engedélyeket a hód vízügyi érdekből történő gyérítésére. Ismereteik szerint más térségekben a gyérítésre való igény ritkán (8), és csak gazdálkodók, vízügyi dolgozók részéről merült fel. 15 adatközlő szerint sok éves távlatban elképzelhető, hogy az ország más térségeiben is szükség vagy legalábbis igény lesz valamilyen fokú letális kontrollra, ugyanakkor 9 adatközlő teljes mértékben elzárkózik ettől a lehetőségtől, vagy természetvédelmi szempontból nem-kívánatosnak tartja az ilyen beavatkozást. Abban az esetben, ha az mégis megvalósul, 18 szakember inkább a csapdázást, 6 inkább a kilövést tartja hatékonynak, könnyebben kivitelezhetönek, 12 személy szerint a két módszer egyaránt alkalmazható. 4 személy kihangsúlyozta, hogy az élvefogó csapdával szemben a nem szelektív, az állatot elpusztító csapda természetvédelmi vagy állatvédelmi szempontból nem elfogadható (például vidra is belekerülhet). Akik még nem hallottak a hazai engedélyekről, azok a gyérítés elsőszámú gátjának a faj védettségét tartották (16). A kilövés hatékonyságát megkérdőjelező adatközlők az elejtés nehézségére (15), tehát az állat éjszakai, rejtett életmódjára, a szükséges időráfordítás nagyságára; a meglőtt állat vízbe menekülésének, és ezáltal a tetem elvesztésének lehetőségére (3); továbbá a szakértelem hiányára (3); az ellenőrizhetőség nehézségére (2); a téves lövés, elsősorban vidra elpusztításának lehetőségére (3) és fontos madárélőhelyeken a hanghatás általi zavarás problémájára (1) hivatkoztak. A vadászok érdekeltségének hiánya szintén fontos tényező (13). „Nem tudom elképzelni manapság azt a vadásztársaságot, aki kiülne éjszakánként hódot lesni” (H26). „Hobbiból nem fogják csinálni” (H39). „Tehát mondjuk a vízügynek érdeke, hogy löni lehessen a hódot, de a vízügynek nincs joga löni, mert a vadászati jogot az állam egy másik szervezetnek adta oda, aki jogosult lenne löni, de ö nem akarja" (H42). 7 adatközlő szerint nem gördülékeny vagy kifejezetten bonyolult az elejtésre és a tetem leadására vonatkozó jogszabályi környezet. A szabályozás, a különféle érdekek és a természetvédelmi szempontok mellett azt is fontos megemlíteni, hogy a hód a társadalom széles 
rétegeinek szimpátiáját élvezi, így a letális beavatkozás lakossági ellenállást is vonhat maga után (5). A gyérítés tehát egyszerre jelent végső konfliktuskezelési eszközt és konfliktust. „,Társadalmi ellenállást generál, vagy épp a társadalom provokálja ki a szükségességét” (H26).

\section{Az elhullás okai}

Az adatközlők legtöbbször az egyedek megfigyelése és az életnyomok észlelése útján szereznek tudomást a hódok jelenlétéről. Az állomány növekedésével párhuzamosan azonban egyre gyakrabban kerülnek elö elhullott vagy sérült állatok. Az adatközlők egyike sem rendelkezett a fajt érintő predációval kapcsolatos tapasztalattal. Ismeretlen okból elhullott hód vaddisznó (1), Romániában pedig medve (1) által fogyasztott tetemét találták meg. 30-an említették, hogy a szakirodalom szerint Európa egyes részein a nagyragadozók (farkasok (25), medvék (16), hiúzok (8)) ejthetnek el hódot. 8 adatközlőnek az volt a véleménye, hogy a predáció Európában sehol sem, vagy csak a legritkább esetben, lokálisan befolyásolhatja az állományt. Amikor arról kérdeztük őket, hogy potenciálisan milyen ragadozóknak eshet zsákmányul a hód az adott térségben, csak óvatos felvetéseket fogalmaztak meg, és gyakran maguk is extrém példának nevezték azokat. Főként a faj rejtett életmódjára, a találkozás esélyére hivatkozva az ilyen interakciókat nem valószínúsítették. Egynél többször hangzott el, hogy a felnőtt hódot megfoghatja nagytestü kóborkutya, pásztorkutya, sakál, a kölyök hódot pedig kutya, sakál, róka, vidra, rétisas, uhu és harcsa. „Bármi nagyon eseti lehet csak” (H36).

Senki sem feltételezi azt, hogy a hódok illegális elpusztítása Magyarországon jelentős mértékü lenne, de egy biztosan és két valószínűleg agyonütött, valamint két lelőtt hódról kaptunk információt. Egy adatközlő hódcsapásra kihelyezett hurkokról, egy másik pedig a hód elpusztítására irányuló fenyegetésről tett említést. További 6 személy úgy gondolta, hogy ilyen esetek biztosan előfordulnak, 21-en határozott „,nem” vagy „,nem valószínüsítem” választ adtak.

28-an találtak már hódtetemet legalább egyszer, vagy a környezetükben talált valaki, de 16 esetben ezeken külsérelmi nyomot nem figyeltek meg. Mindössze két boncolási eredményről számoltak be, egy vemhes hódnál petefészekgyulladás, tályog, egy hódkölyöknél pedig bélgyulladás okozta a pusztulást. További elhullásokokkal kapcsolatos, az adatközlők által ismert, egymástól független esetek: legalább 16 egyed varsába vagy hálóba fulladt, 13 közúti gázolás áldozata lett, 3 territóriumharc következtében egy másik hódtól szerzett sebek miatt pusztult el (többek között ilyen történt a 2004-es, második gemenci telepítés után). Két másik adatközlö is látott már kitépett szőrt, vért, dulakodásnyomokat, ami rivális egyedek összetüzésére utalhatott. A halászati eszközök miatt történt megfulladás a folyóvízi halászat megszünése előtt sokkal több területet érinthetett: „,Ezek az 
esetek nem szoktak napvilágra kerülni" (H17). Olyan is előfordult, hogy egy hód azért pusztult el, mert a szájába akadt horog miatt nem tudott táplálkozni; egy másik hód csónakmotor propellerével ütközött; egy csávázott kukoricát evett és egyre rádőlt a fa (be volt szorulva a foga oda, ahol a fa megtört).

Az árvíz (föként a jeges ár) is lehet kockázatforrás (7). ,Ezt a 400 méteres átlagos dunai szélességet eléggé megnehezíti a hajóforgalom meg a hajók által keltett hullámzás [...] Átúszta a hódkölyök a Dunát, utána kettó órán keresztül pihegett a kövön.” (H23). Mások ilyen hatást nem feltételeznek, az árvíz „,nem pusztitja el, de egy élöhelytöl elveheti a kedvét" (H19).

\section{Értékelés}

\section{Honnan hová terjedt a hód?}

A hódok hazai elterjedésében a spontán kolonizáció jelentőségét mutatja, hogy az állományfelmérési adatok szerint 2003-ban már 80 család élt a Szigetközben (Bozsér 2003), a Hanságban ugyanekkor mindössze 8 helyszínen fordult elő az állat, a szerző kisszámú, egymástól távol eső territóriumokról számolt be (Czabán 2003b). Az FHNPI müködési területén található territóriumok száma 2017-re 534re emelkedett (Szigetközben 352 család, a Hanságban 115 család), ez összesen 1869 példányt jelent, de a valós érték a 2000-et is meghaladhatja, lassú telítődés tapasztalható (Czabán 2017). A hódok korai, Esztergom melletti megjelenéséről a WWF-nek is beszámoltak (WWF Magyarország 2001). A faj Közép-Dunán való terjedésének folyamatát adatközlőink nagy pontossággal követték.

A horvátországi Dráva- és Mura-szakaszra 1996 és 1998 között 29 hódot telepítettek (Valachovič 2014), melyeket előzőleg Bajorországban fogtak be (Schwab \& Schmidbauer 2001, Haarberg 2007). A Dráva magyarországi szakaszán, a Murán és a Fekete-víz nevủ csatornán már a magyarországi visszatelepítések előtt vizsgálták az állományt (Lanszki et al. 2008). A Murán és a Kerkán való 199899-es előfordulás egy jelentésben is megtalálható (Lelkes 2009). A Mura-menti Tájvédelmi Körzetben a 2013-as felmérés 35-45 családot becsült (Lelkes 2013).

A Vas megyei Rába szakaszon a friss adatok szerint 305-350 hód élhet (Czabán 2018). Úgy véljük, hogy az ŐNPI területén érzékelt „exponenciális növekedés” hátterében az állhat, hogy a hód most jut el olyan helyekre, ahol a tevékenysége szembeötlö, azaz nem a hódok száma változik ugrásszerüen, hanem a problémáké.

A kelet-magyarországi visszatelepítések 2002 és 2008 között zajlottak a Tisza számos szakaszán, Tiszalúctól a Sas-érig (Bajomi 2011). A HNPI területén éves rendszerességü monitorozás folyt (Tallósi 2013). A Zagyvát 2006-ban már biztosan elérték (Tallósi 2007). Egy 2014-2016 között végzett felmérés szerint a Sajón 
2014-ben már végig megtalálhatóak voltak a hód életnyomai, és a Hernádra is eljutott a faj (Arlett 2016).

Megjegyezzük, hogy a HNPI területén tévedésből (nem a WWF szervezésében) történt kanadai hód elengedéseket (1991-1994) megelőzően a területen legalább egy - vélhetően eurázsiai - hód már 1988 óta jelen volt (WWF Magyarország 2001, Bajomi 2011), ez akár összefüggésbe is hozható a korábban is említett 1985 és 1990 közötti felső-tiszai adatokkal: az észlelési helyszínek Gulács, Olcsvaapáti és Tarpa (Fintha 2012). Egy adatközlőnk szerint ezek a tiszai egyedek Ukrajnából érkezhettek hazánkba, de a szakirodalom nem támasztja alá, hogy akkoriban hódok éltek volna az ukrán Tisza-szakaszon (Маціборук \& Возняк 2009). Az ezredfordulót megelőzően is igen jelentős volt a hódállomány Ukrajna egyes északabbi folyóin, ennek ellenére Kárpátalján a faj jelenlétét csak 2003 után kezdték tapasztalni (Башта \& Потіш 2012, Barkasi 2016). A Tisza romániai szakaszán az első észlelés 2008-ban történt (Chiş 2015), a Szamoson 2012-ben (Fülöp \& MárkNagy 2013). Az említett szerzők ezeken az ukrajnai és romániai területeken egyaránt azt feltételezik, hogy az egyedek a magyarországi WWF visszatelepítésből származnak. Északkelet-Szlovákiában 1981-ben Lengyelországból levándorolt hódok jelentek meg az Ondava folyón (Čanády et al. 2016), de a két ország állományának összeérése, valamint a potenciális génáramlás lehetősége csak jóval később merült föl (Čanády et al. 2016).

A fenti publikációk egyike sem számol be arról, hogy kanadai hódok is élnek a vizsgált területeken. Az adatközlök által említett kanadai hód adatok ellenére jelenleg az idegenhonos faj előfordulása Magyarországon nem ismert. Az elhullott egyedek koponyáját azonban minden esetben érdemes begyüjteni, és megvizsgálni a két fajt elkülönítő morfológiai bélyegeket (Czabán 2017). Az 1980-as évek elején egy árvíz alkalmával több kanadai hód is megszökött egy osztrák állatkertből (Herberstein Zoo), amelyek megtelepedtek a Freistritz folyón (Komposch 2014). Ez a Pinka-patak medrében 1990-ben talált kanadai hód tetemre is magyarázatot adhat.

Az eurázsiai hód korábbi kipusztulását megelőző legismertebb 1854-es ácsi és 1865-ös zimonyi hódelőfordulás (Brehm 1989) mellett 18. század végi, 19. század eleji források a következő adatokat közölték a környező országokból: Pozsony (1860-as évek) (Mojsisovics 1888), Száva (1844-ben még jelen volt), Somorja (1852-ben agyonütöttek egyet, de ennél jóval később is került elö hódkoponya), Csallóköz (nem bizonyított adat, 1885), Garam mente (19. század végén is, Garamszeg) (Anonymus 1910). Az utolsó romániai adatok pedig az alábbiak: 1824-ben hódokat hoztak a Duna Dubovác és Ómoldova közötti szakaszáról preparálási céllal, továbbá 1857-ben Erdélyből friss hódanyt (castoreumot) szállí- 
tottak egy gyógyszerésznek (Anonymus 1910). Más, általunk ismert források az 1907-es gulácsi kilövést (Fintha 2012) nem említették.

\section{Életnyomok}

Az ország egyes térségeiben a hódok aktuális helyzetét, elterjedését a helyi természetvédelem és a szakirányú kutatás is jól követi, valamint az életnyomokkal kapcsolatban is gazdag az ismeretanyag. Más térségekben a tudásanyag mennyisége és szakmai mélysége változó, de a megkérdezett szakemberek többsége átfogó ismeretekkel rendelkezett kérdéseink valamennyi témakörével kapcsolatban.

Az adatközlők kivétel nélkül a rágást, fadöntést, ágmetszést nevezték meg elsőszámú életnyomként, mely alapján a faj jelenlétére következtetnek, és az októbertől márciusig terjedő periódust tartották a legalkalmasabbnak ennek megfigyelésére. Az állományfelmérés során is a rágások eloszlását vizsgálják a téli periódusban, a rágások sürüsödésének helyét pedig - ami egy általában néhány száz méter hosszú szakasz - egy-egy territórium központi részeként azonosítják (Czabán 2017, Juhász 2018). Az állomány növekedésével a pontos becslés egyre nehezebbé válik, a territóriumok közötti nem rágott szakaszok hossza rövidül, ilyenkor a várak, kotorékok (kizárólag az aktívak), a kijárók, csapások és egyéb életnyomok jelenthetnek segítséget a territórium behatárolásában.

Fontosnak tartjuk cáfolni azt az elterjedt információt, hogy az eurázsiai hód nem épít gátat. Ez a tevékenység általános jelenség Románia egyes térségeiben, például a Kászoni-medencében (Juhász et al. 2017), Magyarországon pedig többek között a Hanság keskeny, sekély csatornáin. A tévhit miatt a hód kisebb vízfolyásokon való megjelenése és az esetlegesen ezzel kapcsolatos gazdálkodói panasz meglepetésként érheti a helyi természetvédőket, valamint a gátat építő egyedeket kanadai hódnak gondolhatják. Európa más országaiban, ahol a gátépítés gyakoribb, részletesen foglalkoznak a faj építési szokásaival és annak ökológiai következményeivel (Hägglund \& Sjöberg 1999, Danilov \& Fyodorov 2012).

\section{Konfliktuskezelés}

Az adatközlők személyes érintettségük hiányában nem tudták összehasonlítani a fásszárúak vagy a nagyobb területek fizikai védelmével kapcsolatos módszerek hatékonyságát, ellenben megfogalmaztak néhány olyan, természetvédelmi érdekkel is összeegyeztethető javaslatot, amelyek a hódkár elleni védekezés lehetőségei között egyelöre sajnos ritkán kerülnek elö. Ezek egyike a vágástéri hulladék parton történő otthagyása, ami a szakirodalom szerint is mérsékelheti a hódkárt (Valachovič 2014, Varju \& Jánoska 2015). Adatközlöink és saját megfigyeléseink szerint az önkormányzatok, a vízügyi kezelők, valamint a gazdálkodók gyakran a kidöntött, vagy éppen csak megkezdett, veszélyesnek minősített fák teljes eltá- 
volítását választják, ami azonban tovább fokozza a fennálló problémát, hiszen a hód újabb fákat fog kirágni a vékony ágak megszerzése érdekében. A bokorfüzesek védelme és telepítése szintén megtalálható egyes szerzők ajánlásai között (Valachovič 2014). Úgy véljük, a bokorfüzeseknek, továbbá a fiatal füzállományoknak hosszú távú, kiemelt szerepük lehet a konfliktusmérséklésben, bár a karvastagságú nyárfák - melyek ugyancsak preferált tápláléktípust jelentenek - megóvására nem nyújtanak garanciát.

Amennyiben a gazdálkodó kerítésépítéssel szeretne védekezni - egy méteres magasságú is elegendő - fontos, hogy a kerítés alját a vízpart irányában elfektesse a földön az aláásás elkerülése érdekében (Valachovič 2014), valamint érdemes 4-5 méter távolságot tartani a partszegély és a kerítés között, máskülönben egy beszakadó üreg átjárót biztosíthat a kerítés túlsó oldalára (Czabán \& Gruber 2018). A riasztóanyagok hatékonysága átmeneti (Czabán 2013). A fák egyedi védelmére csak az erős anyagú dróthálók alkalmasak, melyeknek mindenképpen el kell érniük az 1 méteres magasságot (Valachovič 2014), ám a fatörzs körbekerítése és a kerítés stabilizáló rúddal való ellátása sikeresebb lehet, mivel ha a drót érintkezik a fával, a hód megrághatja a kérget (Vorel 2016). Mezőgazdasági területeken a villanypásztor előnye, hogy mobilis, az elrendezés a hód aktivitásának változásához alkalmazkodva módosítható (Campbell-Palmer et al. 2015). A gátépítésből adódó probléma megszüntetésére az adatközlők által is említett áteresz nyújthat megoldást (pl. Clemson-féle vízszintszabályozó), mely egy köztes, a hódnak is megfelelő szinten stabilizál, és bár Magyarországon még nem készült ilyen, a szerkezet egyszerủen kivitelezhető, magyar nyelvű leírás is található róla (Czabán 2013). A konfliktuskezelés felsorolt eszközei mellett egyre több európai országban napirendre kerül az állomány valamilyen mértékủ szabályozása is (Parz-Gollner \& Hölzler 2009, Campbell-Palmer et al. 2015). Magyarországon 2016-ban az ÉDUVIZIG kérelmét követően 250 példány elejtésére adtak ki engedélyt, de mindössze 12 kilövés valósult meg (Czabán \& Gruber 2018). A különbség hátterében az Eredmények fejezetben ismertetett okok állhatnak. A lokális gyérítés első tapasztalatai után megoldandó kihívást jelent majd a beavatkozás gördülékenységének, ellenőrizhetőségének és a rendszeres állomány-monitorozással történő kontrollálásának együttes megvalósítása.

\section{Az elhullás okai}

A hódok nagyragadozók, elsősorban farkasok általi fogyasztását Európa több országában tapasztalták (Andersone 1999, Nowak et al. 2011). Norvégiában leírtak egy olyan esetet, amikor róka zsákmányolt hódkölyköt (Kile et al. 1996). A farkas esetében olykor hódra való specializálódás is megfigyelhetö, de még ez a ragadozó sem képes szabályozni a populációt (Nitsche 2016). 
Korábban is tettek már kísérlet az eurázsiai hód elhullási okainak hazai öszszegyüjtésére. A 2011-ig beérkezett adatok minimum 37 tetemről szolgáltattak információt, 29 esetben az elhullás oka ismeretlen volt vagy nem részletezték, a Szigetközben ekkor minimum 3 (de inkább több) hálóba, varsába fulladt egyedről tudtak, a telepítések során 3 hód pusztult el, territóriumharc miatt pedig egy (a 2007-es drávai telepítést követően), azonban közúti gázolásról ekkor még nem számoltak be (Bajomi 2011). Varsában, hálóban való megfulladás a Közép-Tiszán is történt (Tallósi 2007). Az elütés, továbbá a territóriumharc következtében szerzett végzetes sérülés az állomány növekedésével válhat gyakorivá (CampbellPalmer et al. 2015). Az utóbbi években történt 13 gázolás is jelzi, hogy a hódok gyakran nagyobb távolságok megtételére kényszerülnek az új élőhelyek keresése során. A faj territoriális viselkedése miatt a csapdázás és a hódok által már benépesített területeken való szabadon engedés a rivális egyedek komoly összetüzéséhez vezethet.

Az elhullott példányokat a későbbiekben jó lenne begyüjteni, és lehetőséget teremteni a tetemek tudományos célú felhasználására.

\section{Észrevételek, javaslatok}

A legtöbb térségben az adatközlök csak a hódok jelenlegi egyedszámának nagyságrendjét merték becsülni, és ezek a hozzávetőleges információk is bizonytalanságokkal terheltek, ezért ebben a cikkben nem közöltük azokat. Fontos lenne, hogy a rendelkezésre álló, szisztematikusan gyüjtött állományfelmérési adatokat és a szórványosan gyüjtött egyéb előfordulási adatokat összegezve a magyarországi állományról minél pontosabb becslést készítsünk. Az egyedszám-növekedés ütemére tekintettel szükségesnek tartjuk, hogy monitorozás kezdődjön azokon a területeken is, ahol a faj észlelési helyeit eddig csak alkalomszerüen rögzítették. A felméréseket legalább néhány évente érdemes megismételni.

A hódállomány növekedésével az egyedek egyre gyakrabban jutnak el olyan területekre, ahol a tevékenységük egyes emberek, elsősorban gazdálkodók számára problémaként realizálódhat. A változó jogszabályi környezet ellenére is fontos, hogy elsőként az együttélés lehetőségeit próbáljuk keresni. A konfliktusmegelőzést jelentősen segítheti, ha a gyakorlati természetvédelem törekszik arra, hogy regionális szinten feltérképezze azokat a területeket, ahol a közeljövőben várható a hódok megjelenése, és a hód számára alkalmas táplálékot nyújtó faültetvények, mezőgazdasági területek, kiskertek a vízpartot érintik. Ezeken a helyszíneken a célzott, elsősorban a hódkár elleni védekezés lehetőségeit bemutató ismeretterjesztés segíthet megelőzni néhány, a tudáshiányból eredő konfliktushelyzetet, valamint a helyiek körében a hódok általános, negatív megítélésének kialakulását. 
A megkérdezett szakemberek nemcsak fontos információkban bővelkedő tapasztalataikat, szakmai tudásukat osztották meg velünk, hanem a hódok későbbi kutatásának irányvonalaival kapcsolatban beszélgetésünk után megfogalmazódott ötleteiket, javaslataikat is. Az adatközlők szükségesnek tartják a rendszeres állományfelmérést, de úgy vélik, hogy a hódrágás és az élőhelyátalakítás ökológiai hatásának kérdésköre sem kellően föltárt. Emellett a következő témaköröket gondolták figyelemre méltónak (5-nél több említés): a hódkár objektív értékelése; az együttélés és a „hódmenedzsment” lehetőségeinek vizsgálata; a helyi ember hódhoz való viszonya a hódkár függvényében, valamint ennek időbeli változása; a területek eltartóképessége, a természetvédelem és a társadalom által elfogadható egyedszám; kolonizáció, vándorlási szokások, rokonsági kapcsolatok a szomszédos egyedek között. „,Jó lett volna tudni, honnan jöttek, merrefelé haladnak” (H21).

A hódok egyedszámának növekedésével a konfliktusok száma és a természeti rendszerekre gyakorolt hatás jelentősége is nőhet. Ezen hatások nyomon követését célzott, terepi vizsgálatokkal érdemes megvalósítani. A természetvédelmi szakemberek részvétele és véleménye jelentősen segítheti későbbi kutatásainkat. A konfliktusok témakörének átfogó feltárásához további érdekcsoportok bevonása szükséges, az erdőgazdálkodók és a vízügyi szakemberek megkérdezése elengedhetetlen. Ismereteinket a vízparti területek közelében élö helyi lakosoktól származó információk szintén gazdagíthatják.

Köszönetnyilvánitás - Szeretnénk köszönetet mondani adatközlöinknek: Albert András, Bajomi Bálint, Bártol István, Bátky Gellért, Czabán Dávid, Csór Sándor, Darányi László, Fülöp Tihamér, Füzfa Zoltán, Gáborik Ákos, Gál Lajos, Gruber Ágnes, Gruber Tamás, Habarics Béla, Harsányi Dezső, Harsányi Krisztián, Hegyeli Zsolt, Herczeg Ferenc, Imecs István, Kleszó András, Kovács Zoltán, Kováts László, Lelkes András, Lontay László, Lovászi Péter, dr. Lőkkös Andor, Megyer Csaba, Mócsán András, Monoki Ákos, Mórocz Attila, Németh Árpád, Öze Péter, Peimli Piroska, Pellinger Attila, Petrovics Zoltán, Platzer Gábor, Právics Márk, Puskás József, Sallai Zoltán, Selmeczi Kovács Ádám, Seres Mihály Nándor, Sipos Tibor, Sugár Szilárd, Szabó Csaba, Szekeres Zsófia, Dr. Szinetár Csaba, dr. Tallósi Béla, Tamás Ádám, Terhes Attila, Tóth Mihály, Urbán László, Varju József, Zákány Albert és két anonim adatközlö. Köszönjük továbbá Bajomi Bálint, Czabán Dávid, Demeter László (MTA ÖK), Fülöp Tihamér, Gruber Tamás és az adatközlők kiválasztásában részt vett személyek szakmai segítségét, a tíz magyarországi nemzeti park igazgatóság együttműködését, valamint a WWF Magyarországnak a rendelkezésünkre bocsátott jelentéseket. Juhász Erika munkáját a Nemzeti Tehetség Program, Emberi Erőforrások Minisztériuma, Emberi Erőforrás Támogatáskezelő támogatta. 


\section{Irodalomjegyzék}

Andersone, Ž. (1999): Beaver: A New Prey of Wolves in Latvia?. - In: Busher, P. E., \& Dzięciołowski, R. M. (eds): Beaver Protection, Management, and Utilization in Europe and North America. Springer, Boston, MA, pp. 103-108. https://dx.doi.org/10.1007/978-1-4615-4781-5 13

Anonymus (1910): Vadászatunk története és jogfejlődése. - Vadász Lap XXXI. évf. 33. szám. Budapest, 1910. november 25. 435-436.

Arlett, P. (2016.): Az eurázsiai hód elöfordulása Borsod megye egyes területein. - BSc szakdolgozat, Kaposvári Egyetem, 62 p.

Baja Ifjúsági Természetvédelmi Egyesület (2011): Az eurázsiai hód (Castor fiber) Alsó-Duna völgyi állományának monitorozása 2011. február - április. - WWF Magyarország, Budapest, 18 p.

Bajomi, B. (2011): Az eurázsiai hód (Castor fiber) visszatelepitésének tapasztalatai Magyarországon. - WWF Magyarország, Budapest, 54 p.

Barkasi, Z. (2016): New Details of the Eurasian Beaver's, Castor fiber (Rodentia, Castoridae), Expansion in the Lowland Part of Transcarpathia, Ukraine. - Vestnik zoologii, 50: 503-510. https:// dx.doi.org/10.1515/vzoo-2016-0057

Башта, А. Т., \& Потіш, Л. А. (2012): Експансія бобра європейського Castor fiber L. в регіоні Українських Карпат. - Науковий вісник Ужгородського університету Серія Біологія, Випуск 33: 144-153.

Bojórquez-Tapia, L. A., Brower, L. P., Castilleja, G., Sánchez-Colón, S., Hernández, M., Calvert, W., Gómez Priego, P., Alcantar, G., Melgarejo, E. D., Solares, M. J., Gutiérrez, L. \& Juárez, M. D. L. (2003): Mapping expert knowledge: redesigning the monarch butterfly biosphere reserve. Conserv. Biol. 17: 367-379. https://doi.org/10.1046/j.1523-1739.2003.01309.x

Bozsér, O. (2001): Hódok az óvilágban. - WWF Magyarország, Budapest, 28 p.

Bozsér, O. (2003): Szigetközi hódelőfordulások 2003 nyarán. - WWF Magyarország, Budapest, Kézirat, 7 p.

Brehm, A. (1989): Hód (Castor fiber). - In: Brehm, A. (szerk.): Az állatok világa egy kötetben (reprint, 1989). - Állami Könyvterjesztő Vállalat, Maecenas Könyvkiadó, Budapest, pp. 560-570.

Campbell-Palmer, R., Schwab, G., Girling, S., Lisle, S. \& Gow, D. (2015): Managing wild Eurasian beavers: a review of European management practices with consideration for Scottish application. - Scottish Natural Heritage Commissioned Report No. 812., 51 p.

Čanády, A., Krišovský, P., Bajomi, B., Huber, A., Czabán, D., \& Olekšák, M. (2016): Is new spread of the European beaver in Pannonian basin an evidence of the species recovery? - European Journal of Ecology, 2: 44-63. https://dx.doi.org /10.1515/eje-2016-0015

Chiş, V. T. (2015): The European beaver (Castor fiber Linnaeus, 1758), Species presence in the Maramureş depression (Romania). - Acta Oecologica Carpatica, 8: 89-194.

Czabán, D. (2003a): A Hanságba visszatelepitett hódok (Castor fiber) élőhely- és táplálékválasztási szokásai. - MSc diplomadolgozat. Eötvös Loránd Tudományegyetem, Budapest, 71 p.

Czabán, D. (2003b): Jelentés a Hanságba visszatelepitett hódok helyzetéröl 2002/2003-ban. - WWF Magyarország, Budapest, Kézirat, 6 p.

Czabán, D. (2013): Éljünk együtt a hódokkal, de hogyan? - WWF Magyarország, Budapest, 41 p.

Czabán, D. (2016): Hódok a Szigetközben. - In: Korda, M. (szerk.): Az erdögazdálkodás hatása az erdők biológiai sokféleségére. Tanulmánygyüjtemény. Duna-Ipoly Nemzeti Park Igazgatóság, Budapest, pp. 403-418.

Czabán, D. (2017): A hód állományának vizsgálata az FHNP müködési területén. - Kutatási jelentés. Fertő-Hanság Nemzeti Park Igazgatóság, Sarród, Kézirat, 45 p.

Czabán, D. (2018): Az eurázsiai hód állományának felmérése a Rába-folyón. - Kutatási jelentés. Őrségi Nemzeti Park Igazgatóság, Öriszentpéter, 25 p. 
Czabán, D. \& Gruber, T. (2018): Visszatértek a hódok - áldás vagy átok? - Term. Közlem. 24: 67-74. https://dx.doi.org/10.20332/tvk-jnatconserv.2018.24.67

Danilov, P. I. \& Fyodorov, F. V. (2012): A comparison of the engineering activities of the Canadian and the European beaver. - In: Book of Abstracts. 6th International beaver symposium 17-20. 09.2012 Ivanic-Grad, Croatia, p. 15.

Dvořák, J. (2013): Diet preference of Eurasian Beaver (Castor fiber L., 1758) in the environment of Oderské vrchy and its influence on the tree species composition of river bank stands. - Acta Universitatis Agriculturae et Silviculturae Mendelianae Brunensis, 61: 1637-1643. https://dx.doi. org/10.11118/actaun201361061637

Fazey, I., Fazey, J. A., Salisbury, J. G., Lindenmayer, D. B., \& Dovers, S. (2006): The nature and role of experiential knowledge for environmental conservation. - Environ. Conserv. 33: 1-10. https://dx.doi.org/10.1017/S037689290600275X

Fintha, I. (2012): Zoológiai megfigyelések Szathmár-Beregben (1954-2006). - Daru füzetek. Hortobágyi Nemzeti Park Igazgatóság, Debrecen, 183 p.

Ganzhorn, J. U. \& Harthun, M. (2000): Food selection by beavers (Castor fiber albicus) in relation to plant chemicals and possible effects of flooding on food quality. - J. Zool. 251: 391-398. http://dx.doi.org/10.1111/j.1469-7998.2000.tb01090.x

Haarberg, O. \& Rosell, F. (2006): Selective foraging on woody plant species by the Eurasian beaver (Castor fiber) in Telemark, Norway. - J. Zool. 270: 201-208. https://dx.doi.org/10.1111/j.14697998.2006.00142.x

Haarberg, O. (2007): Amit a hódról tudni érdemes. Az eurázsiai hód Magyarországon - visszatelepítés, védelem és állományszabályozás. - WWF füzetek 26. WWF Magyarország, Budapest, $30 \mathrm{p}$.

Hägglund, Å., \& Sjöberg, G. (1999): Effects of beaver dams on the fish fauna of forest streams. - Forest. Ecol. Manag., 115(2): 259-266. https://dx.doi.org/10.1016/S0378-1127(98)00404-6

Juhász, E. (2017): Az eurázsiai hód (Castor fiber) táplálék-preferenciájának és területhasználatának vizsgálata. - OTDK dolgozat, Szegedi Tudományegyetem, 39 p.

Juhász, E., Babai, D., Biró, M., Molnár, Z., \& Ulicsni, V. (2017): Az eurázsiai hód (Castor fiber) táplálkozási és fásszárú-használati szokásaival kapcsolatos helyi tudás két évtizeddel a visszatelepítések kezdete után a Kárpát-medencében. - Term. Közlem. 23: 182-200. https://dx.doi. org/10.20332/tvk-jnatconserv.2017.23.182

Juhász, E. (2018): Az eurázsiai hód (Castorfiber LINNAEUS, 1758) elterjedése és tevékenysége a DélAlföldön - Állattani Közlem. 103: 15-32. https://dx.doi.org/10.20331/AllKoz.2018.103.1-2.15

Kile, N. B., Nakke, P. J., Rosell, F. \& Espeland, S. (1996): Red fox, Vulpes vulpes, kills a European beaver, Castor fiber, Kit. Can. Field. Nat. 110: 338-339.

Komposch, B. (2014): Verbreitung und Bestand des Europäischen Bibers (Castor fiber LINNAEUS, 1758) in der Steiermark (Österreich). - Linzer Biol. Beitr. 46: 1277-1320.

Kovács, E., Fabók, V., Kalóczkai, Á. \& Hansen, H. P. (2016): Towards understanding and resolving the conflict related to the Eastern Imperial Eagle (Aquila heliaca) conservation with participatory management planning. - Land Use Policy, 54: 158-168. https://dx.doi.org/10.1016/j.landusepol.2016.02.011

Kovács, E., Kelemen, E., Kalóczkai, Á., Margóczi, K., Pataki, G., Gébert, J., Málovics, Gy., Bálint, B., Roboz, Á., Krasznai Kovács, E. \& Mihók, B. (2015): Understanding the links between ecosystem service trade-offs and conflicts in protected areas. - Ecosyst. Serv., 12: 117-127. https:// dx.doi.org/10.1016/j.ecoser.2014.09.012

Lanszki, J., Müller, E. \& Horváth, G. (2008): Hódok a Dráva folyó vízgyüjtő területén. - Somogyi Múzeumok Közleményei (2008), 18: 135-138.

Lelkes, A. (2009): Hód előfordulás Zala megyében 2009. - WWF Magyarország, Budapest, Kézirat, $7 \mathrm{pp}$. 
Lelkes, A. (2013): Hód elöfordulás Zala megyében 2013. - WWF Magyarország, Budapest, Kézirat, $8 \mathrm{p}$.

Маціборук, П. В., \& Возняк, Р. (2009): Історичні аспекти розповсюдження і екологічні особливості популяції бобра європейського (Castor fiber L.) в Україні - [Електронний ресурс]. Наукові доповіді Національного університету біоресурсів і природокористування України, 2009-2: 12 р.

Mihók, B., Pataki, Gy., Kovács, E., Bartha, D., Csányi, S., Erős, T., Margóczi, K., Standovár, T., Szemethy, L., Török, K., Török, P. et al. (2014): A magyarországi természetvédelem legfontosabb 50 kutatási kérdése a következő 5 évben. - Termvéd Közlem. 20: 1-23.

Mojsisovics, Á. (1888): Az osztrák-magyar monarchia állatvilága. - Vadász Lap 9: 309-310.

Molnár, Z., Kis, J., Vadász, C., Papp, L., Sándor, I., Béres, S., Sinka, G. \& Varga, A. (2016): Common and conflicting objectives and practices of herders and conservation managers: the need for a conservation herder. - Ecosystem Health and Sustainability, 2: e01215. https://dx.doi. org/10.1002/ehs 2.1215

Nitsche, K. A. (2016): The wolf Canis lupus as natural predator of beavers Castor fiber and Castor canadensis. - Russian J. Theriol. 15: 62-67.

Nolet, B. A., Hoekstra, A. \& Ottenheim, M. M. (1994): Selective foraging on woody species by the beaver Castor fiber, and its impact on a riparian willow forest. - Biol. Conserv. 70: 117-128. https://dx.doi.org/10.1016/0006-3207(94)90279-8

Nowak, S., Mysłajek, R. W., Kłosińska, A., \& Gabryś, G. (2011): Diet and prey selection of wolves (Canis lupus) recolonising Western and Central Poland. - Mammalian Biology-Zeitschrift für Säugetierkunde, 7: 709-715. https://dx.doi.org/10.1016/j.mambio.2011.06.007

Parz-Gollner, R. \& Hölzler, G. (2009): Implementing a beaver management in Lower Austria - first results and further steps. - Poster. 5th International Beaver Symposium, Dubingiai, Lithuania, Sep 20-23, 2009.

Právics, M. (2012): Az eurázsiai hód (Castor fiber) állományának és táplálkozásának vizsgálata a Kerka mentén. - Szakdolgozat, Nyugat-Magyarországi Egyetem. 72 p.

Schwab, G. \& Schmidbauer, M. (2001): The Bavarian beaver re-extroductions.- In: Czech, A. \& Schwab, G. (eds): The European Beaver in a new millenium. Proceedings of 2nd European Beaver Symposium, 27-30 Sept. 2000. Carpathian Heritage Society, Krakow, Bialowieza, Poland. pp. 51-53.

Tallósi, B. (2007): Hód-megfigyelések a Közép-Tisza-Jászság Természetvédelmi Tájegység területén 2006. február 10. és 2007. április 27. között. - WWF Magyarország, Budapest, 26 p.

Tallósi, B. (2013): A betelepitett hódpopulációra vonatokozó megfigyelési adatok és a faj természetvédelmi helyzete a Hortobágyi Nemzeti Park Igazgatóság Közép-Tisza-Jászság Természetvédelmi Tájegységének területén 2012 decembere és 2013 márciusa között. - WWF Magyarország, Budapest, 28 p.

Valachovič, D. (2014): Manual of beaver management within Danube river basin. - Danube Parks, $76 \mathrm{p}$.

Varga, A. (2017): A magyarországi fáslegelök, legelöerdők és az erdei legeltetés tájtörténeti, etnoökológiai és természetvédelmi szempontú vizsgálata. - PhD értekezés. Pécsi Tudományegyetem, Biológiai és Sportbiológiai Doktori Iskola, 179 p.

Varju, J. (2008): Az eurázsiai hód monitorozása a Szigetközben. - WWF Magyarország, Budapest, $7 \mathrm{p}$.

Varju, J. \& Jánoska, F. (2015): Az eurázsiai hód (Castor fiber Linnaeus, 1758) fás szárú táplálékpreferenciája és élöhelyhasználata a Mosoni-Dunán. - Erd. Közlem. 5: 129-144. https://dx.doi. org/10.17164/EK.2015.009 
Vorel, A., Dostál, T., Uhlíková, J., Korbelová, J., \& Koudelka, P. (2016): Handbook for Coexisting with beavers. - Czech University of Life Sciences, Prague, $136 \mathrm{p}$.

WWF Magyarország (2001): A magyarországi hódpopuláció elöfordulása a Nemzeti Park Igazgatóságok által végzett megfigyelések alapján - 2001. március. - WWF Magyarország, Budapest, $4 \mathrm{p}$.

Internetes hivatkozások:

http1: http://magyarnemzetiparkok.hu/ Letöltés időpontja: 2018. június 19.

\title{
Függelék
}

A cikkhez tartozó online függelékek a folyóirat honlapján találhatók.

\section{Knowledge of nature conservationists and researchers in the Carpathian basin associated with the Eurasian beaver I: spread, recognisable beaver signs, coexistence and causes of mortality}

\author{
Erika Juhász ${ }^{1}$, Marianna Biró2, Viktor Ulicsni² and Zsolt Molnár ${ }^{2}$ \\ ${ }^{1}$ Eötvös Loránd University, Department of Plant Systematics, Ecology and Theoretical \\ Biology, H-1117 Budapest, Pázmány P. stny. 1/C., Hungary \\ ${ }^{2}$ MTA Centre for Ecological Research, Institute of Ecology and Botany, Hungarian \\ Academy of Sciences, H-2163 Vácrátót, Alkotmány u. 2-4., Hungary
}

E-mail: erikamaria.juhasz@gmail.com

Much professional unpublished knowledge on the Eurasian beaver exists in the local knowledge of local nature conservationists and researchers. We asked experts knowledgeable of beaver in the Carpathian Basin to share their experiences with issues concerning the spread and behavior of the species. We analyzed the information in the light of published literature and looked for new research directions. The beaver is present along all rivers and most streams of the region, the population is growing, and is challenging the peaceful coexistence of humans and beavers. In addition to the felled trees, beaver dams and digging activity of the species are also sources of conflict. The answers of our informants fill several important knowledge gaps. With their help we are able to make a new synthesis about our topics related to the beaver and compare it with data from Western Europe. The second part of our paper will deal with the food habits, building activity and habitat preference of the species.

Keywords: Castor fiber, structured interviews, distribution, coexistence, lethal control 